UNIVERSIDADE DE BRASÍLIA

CENTRO DE EXCELÊNCIA EM TURISMO

\title{
RESORT ECOLÓGICO
}

Thiago Corteletti de Oliveira

Orientador: Dóris Santos de Farias

Banca: Prof. a Susana Pádua

Monografia de Pós-Graduação em Ecoturismo

Brasília - DF: 2004 
UNIVERSIDADE DE BRASÍLIA

CENTRO DE EXCELÊNCIA EM TURISMO

\title{
RESORT ECOLÓGICO
}

\author{
Thiago Corteletti de Oliveira
}

Monografia submetida ao CET - Centro de Excelência em Turismo da Universidade de Brasília, como parte dos requisitos necessários para a obtenção de Especialização em Ecoturismo.

Aprovado por:

Brasília - DF: 2004 
Dedico este trabalho a minha pessoa, que me aturou todos estes séculos À professora Dra Dóris Faria À família Phéla, nas pessoas de Ricardo, Luizinho e Dreithe Ao meu mentor espiritual G.H.R.R.G. Aos meus colegas ecopélvicos da sala Ao senhor Darth Vader e ao Príncipe das Trevas

Aos meus progenitores Gepeto e Zenebrita e hermanos Diocléston e "Oh, Kryspie" Aos meus companheiros mortos na batalha de Waterloo Um abraço para o Projeto Macaco: Banzé, Dickran, Ugueta e Ozny

Aos meus ídolos da melhor banda de Rock do Brasil: Terra Média, nas pessoas de Pélvick, Fisto e Mosscaréballs 
RESUMO

O presente trabalho propõe se afundamentar em um projeto de "Resort Ecológico". O intuito é conceber um novo tipo de Resort, calcado nos ideais do Ecoturismo e que tem no Desenvolvimento Sustentável um fator de vital importância para a boa interação entre o turismo e a natureza. O Resort Ecológico também é criado como um novo campo de atuação para estudantes de Turismo e Ecoturismo do Brasil. Como estudo de caso foi analisado o Resort Costa do Sauípe e os impactos causados no meio ambiente por este empreendimento. Este estudo mostrou a problemática da falta de planejamento e de uso sustentável dos recursos, dando parâmetros para a concepção do Resosrt Ecológico. A criação de um sistema mostrou a importância das diferentes variáveis para a propagação da Cidadania Ambiental, com Educação Ambiental em todas as fases do turismo, desde o primeiro contato do turista com as informações acerca do destino, até sua saída do Resort. A Sustentabilidade é analisada no trabalho como parte componente e inseparável do turismo e a criação do Resort Ecológico como uma ação viável e promissora para fomentar este ideal de Cidadania Ambiental por meio da Educação Ambiental. 
SUMÁRIO

RESUMO iv

UNIDADE 1 INTRODUÇÃO 1

UNIDADE 2: TURISMO E RESORTS 4

2.1. CARACTERÍSTICAS DO PRODUTO RESORT 4

2.1.1 Breve Histórico 4

2.1.2 Os Resorts na Macroeconomia Brasil 5

2.1.3 Características da Demanda 6

2.1.4 Tipos de Roteiros 6

$\begin{array}{ll}\text { 2.1.5 Mercado de Resorts } & 7\end{array}$

2.1.6 Peculiaridades do Produto Resort 8

2.2. CONCEITOS BÁSICOS DA RELAÇÃO TURISMO E RESORTS 9

2.2.1 Turismo 9

2.2.1.1 Produto turístico 10

$\begin{array}{ll}\text { 2.2.1.2 Turista } & 10\end{array}$

2.2.2 Desenvolvimento Sustentável 10

2.2.3 Impacto Ambiental 11

2.2.4 Ecoturismo 12

2.2.5 Ética 13

2.2.6 Meios de Hospedagem 14

$\begin{array}{ll}2.2 .7 \text { Resorts } & 14\end{array}$

2.2.7.1 Complexos turísticos 14

2.2.7.2 Eco-Hotel 15

2.3. A CONCEPÇÃO DE TURISMO E RESORT NO BRASIL 16

2.4. RESORT E SUAS RELAÇÕES COM O MEIO AMBIENTE 18

2.4.1 Benefícios e Impactos do Turismo 18

2.4.1.1 Benefícios $x$ Impactos 19

2.4.2 Impactos do Turismo no Meio Ambiente Natural e suas conseqüências 22

2.4.2.1 Ar 22

2.4.2.2 Água $\quad 22$ 
2.4.2.3 Flora

2.4.2.4 Fauna 25

2.4.3 Os Resorts e o Uso da Paisagem 28

2.4.4 Os Resorts e o Ecoturismo 30

UNIDADE 3: POR UM NOVO CONCEITO DE “RESORT ECOLÓGICO” 32

3.1. ESTUDO DE CASO: COMPLEXO COSTA DO SAUÍPE 32

3.1.1 Impactos Sócioambientais Provocados pelo empreendimento Costa do Sauípe 33

3.2. MONTAGEM DO PROJETO RESORT ECOLÓGICO 39

3.2.1 A Problemática dos Resorts e Sua Influência no

Resort Ecológico 40

3.2.2 Uso do Planejamento Sustentável 40

3.2.3 Sistema Resort Ecológico 43

3.2.4 O Resort Ecológico e sua Interação com as Comunidades 45

3.2.5 Propostas para Caracterização Física e Sustentável do Resort Ecológico $\quad 46$

(A) Estrutura Física $\quad 46$

3.2.5.1 Centro Cultural 46

$\begin{array}{ll}3.2 .5 .2 \text { Sede } & 47\end{array}$

$\begin{array}{ll}3.2 .5 .3 \text { Quartos } & 47\end{array}$

3.2.5.4 Cozinha 48

3.2.5.5 Spa 48

3.2.5.6 Camping 49

(B) Construção Permanente da Sustentabilidade do Fluxo Turístico 49

3.2.5.7 Coleta de Lixo 49

3.2.5.8 Programa de Educação Ambiental 49

UNIDADE 4: RESURSOS HUMANOS PARA O RESORT ECOLÓGICO 51

4.1 O BACHAREL EM TURISMO E O RESORT ECOLÓGICO

4.2 METODOLOGIA DE ABORDAGEM SUSTENTÁVEL 51 
UNIDADE 5: CONCLUSÃO

UNIDADE 6: REFERÊNCIAS BIBLIOGRÁFICAS 
LISTA DE QUADROS

QUADRO 01 - Turismo sustentável x não sustentável

QUADRO 02 - Sistema Resort Ecológico

QUADRO 03: Diferenças entre Ecopousada e Pousada/Hotel 


\section{UNIDADE 1: INTRODUÇÃO}

"A análise da estrutura de toda atividade, seja da natureza, seja do homem, requer, antes de tudo, o estabelecimento de limites no contexto em que ela se processa" (BENI, 1998 pág. 19)

Os grandes complexos hoteleiros, como os Resorts, têm causado grandes impactos nocivos ao meio ambiente natural. Os estudiosos em turismo têm defendido cada vez mais a sustentabilidade aplicada à atividade turística como forma de melhor gerenciar o uso e a conservação dos recursos ambientais. Os investimentos na criação dos Resorts estão aumentando cada vez mais, seguindo o aumento da demanda por este produto. Este é, portanto, um assunto atual e pertinente, pois a falta de planejamento no uso dos bens naturais pela atividade turística, e pelo ser humano, pode resultar na devastação completa dos recursos naturais.

As áreas naturais espalhadas por todo o território nacional representam um grande fator de atratividade turística, principalmente para turistas internacionais. $A$ preocupação acerca da conservação destas áreas deve ser pertinente, fazendo da conscientização de todas pessoas envolvidas no turismo, através de uma Educação Ambiental, a solução para um melhor usufruto dos bens naturais. Utilizar nossas riquezas naturais como matéria-prima para fomento do nosso produto turístico tem dado resultados positivos do ponto de vista econômico, mas do ponto de vista ambiental, o uso indiscriminado tem-nos demonstrado que nossos recursos estarão escassos em muito pouco tempo.

A sustentabilidade dos recursos naturais pode dar-se tanto pela preservação dos seu padrões naturais, quanto por manejo, mais ou menos intensivo, possibilitando assim sua conservação. Faria (2001) chama atenção da importância de se considerar esta diferença entre preservação versus conservação para o turismo, pois constituem diferentes tipos de turismo sustentável. 
A formação de uma nova postura de comportamento perante os impactos do turismo, com o apoio da Educação Ambiental permanente, tem sido fonte de debate em vários fóruns, palestras, workshops e eventos pelo mundo. Os Resorts se enquadram perfeitamente no perfil de uma indústria ambientalmente devastadora, pois suas gigantescas estruturas necessitam ocupar grandes áreas, consumindo os recursos naturais até a última gota. Uma mudança de postura ética, deixando para trás os velhos paradigmas de usufruto e lucro acima de tudo, e visando valorizar os bens naturais, é a chave para a diminuição da devastação causada pelo turismo, e suas grandes estruturas, como os Resorts.

O ideal de consumo sustentável, que se baseia no uso e conservação, é o que viabiliza o ecoturismo, com prefixo "eco" por ser ecologicamente viável, como atividade não só econômica, mas principalmente, ambientalmente positiva, pois os impactos são minimizados, e a renda obtida é revertida também em conservação.

Os Resorts Ecológicos funcionam como um complexo ecoturístico, com prefixo "eco" por: primeiramente, usufruir os bens ecológicos, ou naturais, agregando paisagens naturais, bem como a fuga de volta à natureza, de necessidade do ser humano que hoje vive primordialmente em centros urbanos; mas também - esta a inovação necessária - por qualificar ambientalmente melhor os cidadãos que dele participam, seja como turistas ou profissionais envolvidos na gestão. Esta "Cidadania Ambiental" que deve passar a ser exercitada, depende de diferentes atividades em diferentes tempos e níveis de uma Educação Ambiental, portanto, quase permanente.

Neste estudo baseamo-nos no Sistema Referencial de Turismo - SISTUR, apresentado pelo Professor Dr. Mário Beni (1998). O SISTUR indica um caminho metodológico de interpretar os recursos disponibilizados para o turismo, bem como demonstra a ligação e interdependência dos serviços prestados nas comunidades receptoras para os nativos e turistas, além do uso de bens naturais para a composição do produto turístico. 
O SISTUR apresenta 3 ambientes básicos que são os conjuntos de: Relações Ambientais, Ações Operacionais e Organização Estrutural. O Subsistema Ecológico está incluído no conjunto das Relações Ambientais, apresentando uma interface constante com os Subsistemas Econômico, Social e Cultural que integram o mesmo ambiente. O Subsistema Ecológico do Sistur é base de estudo na área de interação da natureza e exploração turística.

Neste trabalho pretendemos refletir sobre as relações do funcionamento dos Resorts e os impactos ambientais causados pela implementação de sua infraestrutura. Pretendemos, também, analisar a relação entre os turistas e os nativos das regiões onde foi implementada a estrutura, a visão sistêmica - holística deste complexo turístico dentro do macroambiente Brasil. A Educação Ambiental, que responde perfeitamente à necessidade do turismo de ser sustentável, é vista aqui como ação de vital importância para que a natureza seja traduzida para o ser humano e este tenha um comportamento mais consciente. Com base nessas informações pode-se propor a criação do Resort Ecológico nas duas dimensões conceituais: tanto como usufruto de bens ecológicos de maneira sustentável, quanto propiciar uma postura que podemos chamar de Cidadania Ambiental por meio de uma Educação Ambiental permanente. 


\section{UNIDADE 2: TURISMO E RESORTS}

\subsection{CARACTERÍSTICAS DO PRODUTO RESORT}

\subsubsection{Breve histórico}

Nossa tradição em hospedagem foi baseada nos modelos europeus. Os primeiros grandes hotéis brasileiros foram erguidos por imigrantes e quase toda a estrutura que os compunha era importada, pois o Brasil, que não era um país industrializado, comprava no exterior os materiais que não fabricava. A hotelaria brasileira começou a crescer em meados do século XIX, quando muitas capitais e principais cidades de nosso país ganharam hotéis de grande porte. No entanto, só após a II Guerra Mundial é que a atividade hoteleira foi intensificada e hoje possui um padrão de serviços de nível internacional.

Não é de hoje que a hotelaria procura algum tipo de conforto para o próprio bem estar. Em 1703, um anônimo viajante francês de passagem pelo Rio de Janeiro disse que foi obrigado a dormir a bordo do seu navio porque não havia, como na França, hospedarias nem quartos mobiliados para alugar. ${ }^{1}$

Já em 1787, o cirurgião inglês John White considerou o maior incômodo não achar café ou hotéis onde pudesse tomar refresco ou passar uma ou duas noites em terra. Apenas no ano de 1870 que começam a aparecer em São Paulo, os primeiros estabelecimentos hoteleiros dignos dessa dominação. Em 1984, 1.711 hotéis já tinham sido classificados pela EMBRATUR. ${ }^{2}$

\footnotetext{
${ }^{1}$ Adaptação de histórico publicado no site do Correio Brasiliense www.correioweb.com.br, no dia 14/09/01

${ }^{2}$ Publicado na revista "Turismo e Negócios" da editora Capixaba E. S., no $2^{\circ}$ semestre de 2001.
} 


\subsubsection{Os Resorts na Macroeconomia Brasil}

Estes hotéis estão cada vez mais em ascensão no mundo inteiro. Os Resorts se diferenciam dos hotéis tradicionais por possuírem uma temática, pelo grande tamanho de sua estrutura e por atender às necessidades dos hóspedes a ponto destes não precisarem sair das depêndencias do Resort para disporem de alimentação, lazer e outros serviços turísticos. No Brasil, existiam apenas alguns poucos empreendimentos, como o Transamérica da Ilha de Comandatuba, o Club Méd de Itaparica e o Praia do Forte EcoResort, todos na Bahia, além do Club Med Rio das Pedras, em Mangaratiba-R.J.

Devido a grande procura pelos Resorts, dezenas de projetos para a construção de novos destes hotéis estão saindo do papel, no embalo da retomada do turismo interno e na perspectiva de atração de mais turistas estrangeiros. A maioria será no Nordeste, devido a paisagem, o clima e a grande procura por turistas da Europa e Estados Unidos. Além do que, a região concentra todos os apelos para concorrer com outros Resorts do mundo que oferecem sol, areia e mar.

Os Resorts exigem investimento alto, planejamento cuidadoso e mão-deobra qualificada. No Brasil, os investimentos têm sido consideráveis, mas sem ater-se à relevância dos aspectos ambientais. O Costa do Sauípe na Bahia, é um conjunto de cinco Resorts e um campo de golfe de dezoito buracos. Este tipo de hotel atende a clientes estrangeiros acostumados com Resorts de alto luxo. Existem projetos para Resorts em boa parte do litoral nordestino como Alagoas, Rio Grande do Norte e em Pernambuco. Os empreendimentos que já existem também possuem planejamento para expansão. ${ }^{3}$

\footnotetext{
${ }^{3}$ Publicado na revista "Turismo e Negócios" da editora Capixaba E. S., no $1^{\circ}$ semestre de 1998.
} 


\subsubsection{Características da Demanda}

Ribeiro e Barros (1999) classificam os turistas consumidores do produto Resort como praticantes do turismo "tipo Cancún", que requerem ampla infraestrutura e serviços, alimentando-se dos fluxos internacionais de turistas e apresentando retórica conservacionista.

Em relação ao usuário deste tipo de turismo, podemos considerar o perfil definido por Ruschmann (1995) para o perfil do ecoturista, pois é bastante similar ao turista que consome o produto Resort:

- Poder aquisitivo: médio/elevado

- Sexo: ambos

- Faixa etária: 10-60 anos (com predomínio 30-40)

- Nível cultural: médio/elevado

\subsubsection{Tipos de Roteiros}

Fazendo uma adaptação de "Tipos de roteiros operados pelo mercado turístico", obra de Célia Serrano (2000), podemos ainda classificar o turismo praticado nos Resorts dentro das seguintes variáveis:

- Quanto à duração: médio (feriados, quatro ou cinco dias) ou longo (mais de uma semana);

- Quanto à atividade principal: híbrido (mais de um tipo de atividades no mesmo roteiro, como passeios de lancha e prática de golf, por exemplo);

- Quanto à dificuldade: fácil (para iniciantes/não sedentários);

- Quanto à organização: convencionais (a operadora se responsabiliza por 
todos os serviços oferecidos);

- Quanto ao nível da estrutura e serviços oferecidos: sofisticado;

\subsubsection{Mercado de Resorts}

Analisando o mercado de Resorts no mundo, para podermos melhor entender suas dimensões, vemos que, baseado nos estudos de José Ernesto Marino Neto (em LAGE e MILONE, 2000), este é um dos mercados que mais cresce no mundo. Países como Coréia do Sul, África do Sul, Vietnã, já entraram no mercado de oferta do produto Resort. Nos últimos anos o aumento do fluxo de turistas vindos da Europa com destino à América do Norte foi originado pela procura dos Resorts de Cancun (México), Flórida e Havaí. Além destes destinos, países como Jamaica, República Dominicana e Trinidad e Tobago, também têm despertado interesse dos turistas europeus.

Seguindo os estudos de Ernesto Marino (em LAGE e MILONE, 2000, pág. 179), as estratégias mercadológicas para atração dos turistas, possuem seus diferenciais de acordo com cada destino, principalmente nos países da América Central. Podemos particularizar alguns destes segmentos e onde geralmente ocorrem:

- Férias familiares: Flórida e Ilhas Caribenhas;

- Casamentos e luas-de-mel: Santa Lúcia, Barbados e outras ilhas;

- Turismo náutico: Ilhas Leeward;

- Mergulho submarino: todo o Caribe;

- Golfe: Jamaica; 
No Brasil, o mercado de Resorts apresenta grande ascensão na última década. Existe uma grande concentração destes empreendimentos no litoral Nordestino, e a procura por parte de turistas estrangeiros, com alto poder aquisitivo, tem aumentado ainda mais os investimentos em construções de novos complexos. De acordo com um estudo realizado pela empresa Odebrecht em 1992, na Costa de Sauípe, Bahia, o potencial para aquele lugar foi relatado como sendo Resort.

No plano diretor da Costa do Sauípe realizado por uma empresa de consultoria internacional, sob direção do grupo Odebrecht, foi traçado como meta, dentre outras, "trazer o mercado internacional de volta para o Brasil por meio do design e da construção de um Resort de classe mundial" (LAGE e MILONE, 2000, pág. 189). O caso do Resort Costa do Sauípe será o estudo de caso deste trabalho.

\subsubsection{Peculiaridades do Produto Resort}

O mercado de Resorts vem sendo desenvolvido com base na concepção de mega estruturas ou Mega Resorts. Esta concepção acata a procura da demanda por hotéis que possuam várias facilidades nos serviços, vida noturna, diversos esportes como golf, tênis e equitação.

Uma mega estrutura requer muito espaço e investimentos vultuosos de capital, o que pode, à curto prazo, ser sinônimo de prejuízo já que, numa simples análise econômica, grandes estruturas necessitam de muitos turistas com auto poder aquisitivo, o que não é uma realidade no Brasil e, além disso, causam grandes impactos ambientais. O produto destinado realmente ao ecoturismo definitivamente não combina com grandes complexos, mas com empreendimentos de pequeno porte. Com esta concepção de tamanho reduzido é que se baseia o projeto do Resort Ecológico. 


\subsection{CONCEITOS BÁSICOS DA RELAÇÃO TURISMO E RESORTS}

\subsubsection{Turismo}

O conceito de turismo se faz necessário porque a má interpretação da atividade é o que tem causado impactos nocivos na sociedade e na natureza como um todo.

De acordo com Pearce (2003, pág. 25) "O turismo é uma atividade que diz respeito essencialmente a pessoas e lugares: a lugares que um grupo de pessoas deixa, visita ou que nele está de passagem; a outro grupo de pessoas, as que tornam possível a viagem, e outras ainda, aquelas com as quais cruzará pelo caminho".

Para Molina (2001, pág. 10)“...o turismo é resultado de uma cultura universal, mas também transcende as culturas locais nas quais se manifesta."

Através da definição de Wahab (1976) turismo é uma atividade humana intencional que serve como meio de comunicação e integração entre os povos.

Com uma definição de caráter econômico, o turismo foi definido por McIntosh, em 1977, como a ciência, a arte e a atividade de atrair e transportar visitantes, alojá-los e satisfazer suas necessidades e desejos.

Como vimos em algumas definições, o Turismo necessita ser praticado com muito cuidado pois envolve diversos fatores. Um erro no processo de instalação de um complexo turístico como um Resort, pode prejudicar não só as pessoas e recursos envolvidos, mas toda uma história, através de atos que venham a descaracterizar e destruir culturas. 
2.2.1.1 Produto turístico: segundo Lage e Milone (2000, pág 27), consiste num "conjunto de prestações materiais e imateriais, que são oferecidas como o propósito de satisfazer os desejos ou as expectativas dos turistas", composto por:

- atrativos: elementos que determinam a escolha do turista;

- facilidades: permitem a permanência do turista no local visitado;

- acesso: meios que possibilitam o deslocamento do turista;

2.2.1.2 Turista: para as Nações Unidas trata-se de visitantes temporários que permaneçam pelo menos vinte e quatro horas no país visitado, cuja finalidade de viajem pode ser classificada sob um dos seguintes tópicos: lazer (recreação, férias, saúde, estudo, religião, e esporte), negócios, família, missões e conferências;

\subsubsection{Desenvolvimento Sustentável}

De acordo com Faria (2001, pág 15) o conceito de sustentabilidade:

"pode ser enfocado sob três diferentes aspectos: a) uso sustentável, que ocorre quando os seres humanos utilizam os recursos renováveis, permitindo que os processos naturais de reposição ocorram e assim o sistema poderá renovar-se indefinidamente; b) crescimento sustentável, onde a questão básica que se impõe é se o crescimento econômico leva ou não em consideração a limitação de recursos, sem o que ocorrerá degradação do ambiente pois não pode haver crescimento que seja sustentável sem o controle do crescimento populacional e do consumo per capta de recursos; e, por fim, c) desenvolvimento sustentável, o termo mais usado e o de mais difícil definição. De acordo com Mangel (1993), o desenvolvimento sustentável torna-se uma tarefa impossível quando sinônimo de crescimento sustentável que envolva crescimento da população e do consumo de recursos, mas não quando tenha o significado de uso sustentável, tornando-se 
então um imperativo. Ou seja, em se tratando de desenvolvimento sustentável, o crescimento descontrolado mina as possibilidades de promoção da melhoria social e econômica da população do planeta, que poderia ser promovida pelo uso sustentável de recursos renováveis."

Segundo a World Comission of Enviroment and Development (2001) o desenvolvimento sustentável é considerado aquele que atende às necessidades atuais sem comprometer a possibilidade do usufruto dos recursos pelas gerações futuras.

Com base no que Ever (1982) diz sobre turismo e sustentabilidade, podemos salientar o turismo sustentável como sendo um turismo, cuja infraestrutura a ele relacionada opera dentro das capacidades naturais para regeneração e futura produtividade dos recursos.

A ideologia do desenvolvimento sustentável é salvaguardar o ambiente e a qualidade de vida na comunidade regional, com um desenvolver econômico e ecologicamente sustentável, onde a conservação e preservação ambiental são metas que garantam às gerações futuras empregos, distribuição de renda, usufruto dos bens naturais, conscientização sobre a preservação; enfim, garantia de vida melhor para as gerações vindouras.

O Desenvolvimento Sustentável é de extrema importância para o turismo, pois é por meio do uso sustentável dos recursos que atividades turísticas de longo prazo serão mantidas por um grande período, sem prejudicar áreas, pessoas e atividades envolvidas.

\subsubsection{Impacto Ambiental}

Segundo o Ibama (2001), impacto ambiental é qualquer alteração das propriedades físicas, químicas e biológicas do meio ambiente, causado por 
qualquer forma de matéria ou energia.

De acordo com Rushmann (1995), o meio ambiente é a base econômica da atividade turístico recreativa e apresenta oportunidades e limitações. As limitações relacionam-se com a chamada "capacidade de carga", que é definida por Boo (1992) como "o número máximo de visitantes (dia/mês/ano) que uma área pode suportar, antes que ocorram alterações no meio fisico e sociocultural". Assim, a capacidade de carga dita a capacidade máxima de visitantes e de equipamentos que uma área pode suportar. Se esta capacidade for excedida, os recursos naturais são deteriorados, causando impactos ambientais.

\subsubsection{Ecoturismo}

Segundo o Sebrae (1995, pág 7) a definição de Turismo Ecológico é “ turismo desenvolvido em áreas naturais, onde os seus consumidores procuram usufruir ao máximo a natureza, minimizando os impactos que possam causar, além de desenvolver uma consciência ou compreenção ecológica."

De acordo com Selva e Coutinho (em FARIA, 2001, pág. 70) o Ecoturismo é "o segmento do turismo baseado nas propostas do desenvolvimento sustentável".

Segundo Barros (1995) ecoturismo é um segmento da atividade turística que, de forma sustentável, utiliza o patrimônio natural e cultural, incentivando sua conservação e buscando formar uma consciência ambientalista.

Sintetizando a definição para esta atividade podemos dizer que ecoturismo é um segmento da atividade turística que utiliza de forma sustentável o patrimônio natural e cultural, incentivando sua conservação, buscando a formação de uma consciência ambientalista e promovendo o bem-estar das populações. A comparação proposta por Faria (2001, pág.69) entre Ecoturismo e Turismo 
Ecológico demonstra que, "apesar de termos definidos estes termos, a prática do turismo na natureza ainda está longe do ideal teórico", mas o projeto do Resort Ecológico realmente propõe a prática das premissas de uso e preservação propostas pelos autores aqui citados, que vão de encontro às premissas da sustentabilidade.

\subsection{5 Ética}

A conceituação de ética se faz necessário, pois os vários paradigmas e novas posturas de pensamentos aqui apresentados terão fundamento nessa conceituação. Abaixo seguem definições retiradas do livro "O que é Ética":

- Sócrates ( 470-399 a.C.): ética é convicção pessoal, adquirida através de um processo de consulta ao seu "demônio interior", na tentativa de compreender a justiça das leis;

- Aristóteles (384-322 a.C.): a ética é marcada pelos fins que devem ser alcançados para que o homem atinja a felicidade (eudaimonia);

- Kani (1724-1804): as questões éticas para Kani, estão no dever. O homem deve se perguntar qual o seu dever, diante de cada ordem, de cada lei, de cada costume, para ser um homem livre;

- Hagel (1770-1831): para ele, o ideal ético estava numa vida livre dentro de um Estado livre, um Estado de direito que preservasse os direitos dos homens e Ihes cobrasse seus deveres, onde a consciência moral e as leis do direito não estivessem nem separadas e nem em contradição;

- Pensamento social do século XX: a ética se volta em primeiro lugar sobre as relações sociais, acima das questões do céu, preocupando-se com a terra e 
procurando apressar a construção de um mundo mais humano e justo;

- Vazquez (1985): ética é teoria, investigação ou explicação de um tipo de experiência humana ou forma de comportamento dos homens e da moral, considerada na sua totalidade, diversidade e variedade.

- Valls (1986): a ética é a teoria ou a ciência do comportamento moral dos homens em sociedade.

Com base em Irving (2002), o desenvolvimento sustentável da atividade turística deve incorporar princípios e valores éticos, uma nova forma de pensar a democratização de oportunidades e benefícios, e um novo modelo de implementação de projetos, centrado em parceria, co-responsabilidade e participação.

\subsubsection{Meios de Hospedagem}

Em acordo com a Embratur (2001), temos a seguinte definição para Meios de Hospedagem de Turismo: são os empreendimentos ou estabelecimentos destinados a prestar serviços de hospedagem em aposentos mobiliados e equipados, alimentação e outros necessários aos usuários;

\subsubsection{Resorts}

A definição do Resort Ecológico deve abranger, em parte, a idéia de complexo turístico e eco hotel como definidos a seguir:

2.2.7.1 Complexos turísticos: "empreendimentos de grande envergadura, que apresentam instalações e serviços variados como: meios de hospedagem, condomínios, equipamentos de esporte, lazer e outros. Estão situados em áreas 
delimitadas, onde já existia uma natural vocação recreacional" (BENI, 1998, pág. 312).

2.2.7.2 Eco-Hotel: "estabelecimento comercial de hospedagem situado em florestas tropicais ou em áreas naturais protegidas, com arquitetura e estrutura construtiva adaptadas às condições do meio ambiente no sentido de preservar a integridade da paisagem e integrar o hóspede no primitivismo do entorno original".(BENI 1998, pág. 300)

Mário Beni(1998, pág. 54), ao tratar de seu Subsistema Ecológico, cita que "o homem tem a necessidade de retornar à natureza, de encontro à mãe Terra, mas a publicidade, Ihe reforçando esta idéia, acaba por apanhá-lo, colocando-o em balneários massificados, rápidos e alienados como a jaula dourada e confortável da qual saiu". Esta visão de balneários massificados e alienadores, é tida, para muitos estudiosos, como a definição do Resort. Este é um empreendimento que acata muitos interesses, e que possui uma máquina de venda de ampla ação, podendo realmente alienar os turistas que vêm a consumir seu produto.

Neste trabalho, a definição de Resorts agrega a proposta de lazer apresentada pelos próprios Resorts, como por exemplo o Resort Costa do Sauípe, mas com um ideal focado principalmente na sustentabilidade aplicada em todos os estágios de concepção do empreendimento. A sustentabilidade social, econômica e cultural de todos os atores envolvidos diretamente com Resort é o objetivo principal de trabalho para que o Resort Ecológico seja idealizado. Além deste componente, haverá também um componente temático - educacional que assumirá a ecologia como tema e como finalidade educativa, por meio de um programa contínuo de Educação Ambiental, com a finalidade de promover uma Cidadania Ambiental. 


\subsection{A CONCEPÇÃO DE TURISMO E RESORT NO BRASIL}

A situação atual do turismo no Brasil deve ser consultada para a melhor compreensão do assunto Resort. A partir de uma análise do contexto turístico no Brasil, detendo-nos na questão dos impactos ligados diretamente a instalação dos complexos turístico Resorts, podemos situar o turismo como agente de desenvolvimento econômico. É também importante abordar a indiscriminada degradação do meio ambiente causada pelo turismo, neste caso não apenas de áreas de proteção ou outras com esta mesma finalidade, mas sim do meio ambiente urbano, que no caso das cidades turísticas agregam variáveis sociais e "ambientais".

A cidade turística é um espaço no qual os agentes sociais atuam no sentido da valorização imobiliária, comumente negligenciando os aspectos negativos que permeiam a implantação de complexos turísticos, como os Resorts, voltados ao uso da paisagem. Os interesses econômicos têm sido hegemônicos e, no caso do turismo, a questão do consumo ganha novas características, pois não é apenas o setor de serviços através de suas lojas, shoppings, bares entre outros de atendimento ao turista que se põe à disposição do processo produtivo do turismo. Há a paisagem como uma nova, preciosa e frágil contribuição na formatação do produto turístico.

Na visão de Ruschmann (1997) o turismo é um enorme gerador de riquezas e ao mesmo tempo uma força que agride a natureza, as culturas, os territórios e as sociedades. Ela ainda ressalta que o caráter econômico desta atividade não permite considerá-la "boa" ou "má", nem mesmo como uma atividade que poderia preservar ou destruir a natureza.

Com a cultura até então do turismo de massa, dado o retorno comercial que advém desta atividade, poucos esforços foram destinados à implementação de um projeto que viabilizasse uma política conjunta de desenvolvimento e 
sustentabilidade, sobretudo nos espaços urbanos litorâneos. Tratam-se de áreas que no caso do Brasil, apresentam frágeis ecossistemas de alta concentração populacional, altos desníveis na estrutura social, fatores que somados à forte tendência de valorização do espaço, podendo tornarem-se áreas que representam um verdadeiro barril de pólvora. São nestas áreas que comumente instalam-se os Resorts.

No Brasil a concepção de meio ambiente urbano ainda não se encontra difundida. Este fato pode estar relacionado às dificuldades de atrelar interesses econômicos aos de desenvolvimento social, considerando os modelos de implantação desses empreendimentos nas últimas décadas, sobretudo na região Nordeste do país, onde há uma expressiva concentração do turismo de massa no perímetro litorâneo. Neste caso, como nos demais do país, não foi o turismo que promoveu o surgimento das cidades, a exemplo do já quase clássico caso de Cancún, no México. Aqui foi a necessidade espontânea versus a necessidade forçada de promover a atividade turística, impulsionando o crescimento das áreas urbanas e promovendo uma reconfiguração espacial com a formação de novas áreas sociais. Estas áreas, embora segregadas, há centrais, funcionais, todas objetivando atender cada vez mais ao acúmulo de capital (SERRANO, 2000).

Cidades como Rio de Janeiro, Salvador e Recife são exemplos de áreas urbanas que já experimentavam um alto grau de desenvolvimento e onde o turismo se consolidou posteriormente a outras atividade econômicas. Nestes casos é complexo afirmar que atividade turística seja um dos principais vilões no quadro de degradação sócio-ambiental, mas seria ingênuo não considerar a importância e a influência desta atividade, tanto no que se refere ao crescimento da economia, quanto ao processo de exclusão social e devastação do meio ambiente (LAGE e MILONE, 2000).

Nesta mesma ótica temos as cidades que tiveram sua economia e dinâmica funcional estreitamente atrelada ao desenvolvimento do turismo. É certo que em 
ambos os casos, as ações acerca de questões relacionadas à sustentabilidade urbana foram quase sempre inexistentes. Neste último caso contudo, o quadro é ainda mais crítico, pois se tratam de cidades que dependem parcialmente ou totalmente do turismo, tornando-as reféns das imposições e ações dos agentes sociais que aí atuam. Referimo-nos aqui, mais precisamente, ao poder público, seja na esfera Federal, Estadual ou Municipal, cujos esforços dirigem-se a atender interesses dos agentes econômicos representados pelos que detêm os meios de produção; pelos agentes imobiliários e fundiários, que dominam entre outros setores o de serviços e, por sua vez, contam com a cumplicidade do poder público para submeterem a outra parcela, os grupos sociais excluídos, à total marginalização do fluxo de capital dentro do sistema (BENI 98).

Este conjunto de problemas envolvendo o turismo e a questão ambiental urbana, demonstram que estamos ainda distantes de promover um modelo de desenvolvimento sustentável, principalmente quando esta idéia de desenvolvimento esbarra na pressão exercida pelos interesses econômicos .A análise do meio-ambiente urbano nos leva à fazer um paralelo com os Resorts, objeto de estudo nesta monografia.

\subsection{RESORT E SUAS RELAÇÕES COM O MEIO AMBIENTE}

Para uma análise completa da interação Resort e Meio ambiente, é necessário caracterizar os benefícios e os impactos causados pelo turismo no meio ambiente.

\subsubsection{Benefícios e Impactos do Turismo}

O turismo não pode ser considerado uma "indústria limpa". O turismo mundial tem sido um consumidor (ou destruidor) voraz das paisagens, um instrumento de descaracterização das comunidades receptoras e de sua cultura, e 
um grande causador de uma ampla gama de impactos no ambiente natural. $O$ setor hoteleiro é responsável por boa parte dos resíduos poluentes despejados na natureza, situação em que se enquadram os Resorts.

Os turistas não são alvos de programas de conscientização por meio de uma Educação Ambiental, que visa integrar o ser humano ao ambiente visitado, sem causar tamanhas e irreversíveis alterações. É necessário que o turismo de fato se utilize de instrumentos tecnológicos adequados e de metodologias científicas que busquem o planejamento, implantação e gestão de forma sustentável e responsável.

\subsubsection{Benefícios $x$ Impactos}

Com base nas definições do Ibama (2001), atualmente considera-se o termo "impacto" como qualquer alteração negativa nas propriedades físicas, químicas e biológicas do meio ambiente, causada por qualquer forma de matéria ou energia, decorrentes das atividades humanas que direta ou indiretamente prejudiquem:

- a saúde, a segurança e o bem estar da população;

- as atividades sociais e econômicas;

- a biota;

- as condições estéticas e sanitárias do meio ambiente;

- a qualidade dos recursos naturais.

Com adaptações de Serrano (2000), Beni (1998), Ruschmann (1997) e Inskeep (1991), apresentamos abaixo os principais impactos e benefícios do turismo em nível local e regional, lembrando que os impactos podem ser minimizados e os benefícios potencializados, desde que suas atividades sejam 
corretamente planejadas.

Impactos Socioculturais:

- perda de valores culturais tradicionais;

- conflitos entre usuários da comunidade e visitantes.

Benefícios Socioculturais:

- investimentos na infra-estrutura viária, de abastecimento, equipamentos médicos e sanitários;

- estímulo ao artesanato local e às manifestações culturais tradicionais.

Impactos Econômicos:

- sobrevalorização de terras e imóveis;

- aumento do custo de vida;

- pressões para a super-exploração de áreas turísticas.

Benefícios Econômicos:

- geração de emprego;

- melhor distribuição de renda.

Impactos sobre o Meio Físico:

- descaracterização da paisagem;

- poluição da água, do solo, sonora e do ar;

Benefícios sobre o Meio Físico:

- manutenção da paisagem; 
- controle da poluição.

Impactos sobre a Vida Silvestre:

- alterações na reprodução, comportamento e hábitos alimentares da biota;

- coleta e comércio ilegal de espécies silvestres;

- erosão e desmatamento em trilhas;

- estradas inadequadas;

- meios de transporte poluentes.

Benefícios sobre a Vida Silvestre:

- auxílio na conservação de áreas naturais;

- conscientização sobre o equilíbrio do meio ambiente.

Oportunidades Educacionais:

- conscientização do público visitante e dos moradores próximos a áreas naturais por meio de programas de Educação Ambiental;

- valorização e sensibilização do público envolvido ante a importância da conservação da natureza;

- aprendizado por meio de experiência direta com o ambiente natural.

Os impactos e benefícios advindos do turismo estão diretamente relacionados com a questão da sustentabilidade, que atua para reduzir os impactos negativos e manter os benefícios da atividade. 


\subsubsection{Impactos do Turismo no Meio Ambiente Natural e suas conseqüências}

A atividade turística quando causadora de impactos no meio ambiente, tende à alterar os ecossistemas naturais, bem como os padrões socioculturais das populações que vivem nas áreas receptoras. Analisando os impactos no meio ambiente natural, no qual é inserido a infra-estrutura do Resort, vamos nomear áreas de impacto causado pelo fluxo turístico, sendo estas: o ar, a água, a flora e a fauna.

\subsubsection{1 $\mathrm{Ar}$}

O ar é, provavelmente, o elemento menos afetado pelo fenômeno turístico. No entanto, alguma poluição atmosférica pode ser imputada à indústria turística. $\mathrm{O}$ turismo envolve o movimento de pessoas. Em locais de maior afluência turística pode ocorrer contaminação atmosférica, devido sobretudo à ocorrência de congestionamentos de tráfego motorizado. Os veículos recreativos podem ser outra fonte de poluição atmosférica.

Inskeep (1991) defende que a falta de planejamento contribui para a contaminação atmosférica através de poeiras geradas pelos desenvolvimentos turísticos.Com base no que é dito por Inskeep (op.cit.), o impacto ambiental pode ser direto ou indireto assim como acontece com o impacto econômico .

\subsubsection{2 Água}

O turismo pode afetar este recurso em termos de quantidade e de qualidade. Alterações ao nível da quantidade de água subterrânea podem resultar de vários fatores, nomeadamente:

- consumo turístico: o turismo coloca grandes pressões ao nível dos 
consumos de água (piscinas, estruturas de alojamento, campos de golfe). Em épocas de grande concentração turística, os valores consumidos chegam a mais do dobro do usual. Este impacto afeta também as águas de superfície quando estas são fonte de abastecimento doméstico.

- alteração da permeabilidade dos solos: sempre que o turismo implique um aumento de urbanização e de infra-estruturas associadas, está a contribuir para um aumento das áreas impermeabilizadas, o que por sua vez poderá ter implicações nas recargas dos aqüíferos. Trata-se de um impacto ao nível do consumo, pode assumir alguma expressão particularmente se ocorrer em zonas de importante recarga. A análise das alterações ao nível da qualidade deverá incluir águas subterrâneas e águas de superfície.

- águas subterrâneas: no que respeita às águas subterrâneas, alterações ao nível da quantidade poderão provocar alterações na sua qualidade, nomeadamente:

- intrusão salina: é um fenômeno de salinização de aqüíferos da orla marítima. Uma sobre exploração do aqüífero de água doce faz diminuir a pressão permitindo infiltrações de água salgada. O processo de recuperação é lento o que acentua a gravidade do problema (LENCASTRE e FRANCO,1992). Para além do turismo, a atividade econômica, bem como a qualidade de vida dos residentes são afetadas por este fenômeno.

- água de superfície: a atividade turística pode provocar alterações na qualidade das águas de superfície através da ação poluidora dos barcos de recreio, afetando em particular águas dos rios e lagos. De acordo com estudos efetuados pela Agência de Proteção ambiental dos EUA, os barcos a motor de dois tempos são particularmente poluidores uma vez que vertem cerca de um terço do combustível que consomem (HILCHEY,1994). Os resíduos dos barcos provocam também problemas adicionais nas marinas. 
Para Pearce (1989), uma área de grande pressão no ambiente resulta da produção ou aumento de águas residuais. O problema mais generalizado é a poluição devido às descargas de afluentes tratados inadequadamente. Em situações extremas pode acelerar o fenômeno de eutrofização com incidência em lagoas, lagos e rios. A poluição ao nível das águas dos mares depende das descargas e das condições de eliminação da poluição. A poluição da água do mar afeta não só a saúde pública como a fauna e flora marinha.

\subsubsection{Flora}

É uma importante atração dos destinos turísticos, pois também é formadora de paisagens, e uma das suas principais vítimas devido a:

- desenvolvimento descontrolado do turismo ao longo da costa alterando, destruindo habitats;

- desequilíbrio do ecossistema devido à ação de colecionadores (flores, fungos, cactos);

- descuido na utilização de fogo em parques;

- abate de árvores (para construção de campos de golfe, por exemplo);

- acumulação de lixo, responsável pela alteração dos nutrientes do solo, das condições de luminosidade e do ar;

- tráfego pedestre e de veículos diretamente sobre a vegetação (particularmente grave nas dunas);

- prática de campismo, implicando remoção de vegetação; 
Os pontos acima referidos podem alterar:

- a percentagem de cobertura vegetal;

- a diversidade das espécies;

- a estrutura de idades do ecossistema botânico;

- a diversidade dos habitats;

\subsubsection{Fauna}

A extensão do turismo tem impactos em:

- habitats da vida selvagem: o turismo pode afetar a fauna através das alterações dos ecossistemas da flora, seus habitats de alimentação e de reprodução. A reação das espécies ao impacto do turismo dependem de vários fatores, nomeadamente de espécie para espécie e de região para região. Os efeitos diretos na atividade turística na vida selvagem dependem da intensidade do desenvolvimento turístico, da resiliência das espécies e da sua capacidade de adaptação (MATHIESON e WALL.1982).

- padrões de comportamento animal: relacionando alimentação, reprodução e migração. Estas alterações podem ter impacto na abundância e mesmo na subsistência das espécies. A presença dos turistas (por exemplo, observadores de aves) pode alterar as relações entre presa e predador.

Especificando a montagem da infra-estrutura do Resort, os impactos começam à surgir antes mesmo da ação turística. Quando uma área de mangue é desmatada para abrigar os equipamentos, como barcos, ou quando o fundo dos 
rios é dragado para obtenção de areia, os ecossistemas são irreversivelmente afetados.

A montagem de estruturas gigantescas como Resorts funcionam como aceleradores dos processos de erosão, sobretudo em zonas instáveis, como falésias e dunas. Em áreas litorâneas, os impactos são sentidos na configuração da linha de costa, que é resultado de um processo dinâmico e natural. Certas zonas são afetadas por processos erosivos enquanto, em compensação, outras são alvo de processos de sedimentação. A ação humana e o mau uso dos ambientes costeiros e marinhos, ecossistemas frágeis e particularmente vulneráveis a desenvolvimentos impróprios, intensificam e aceleram esses processos.

Quando o desenvolvimento da estrutura ocorre na borda de falésias, o aumento de peso acelera o deslizamento das mesmas. A alteração dos sistemas de drenagem pluvial, devido à impermeabilização com concentração num único dreno, origina fraturas, enfraquecendo a estrutura da falésia. As dunas são exemplo de estrutura natural muito apreciada pelo turismo, por "poder abrigar" a infra-estrutura, e por formar paisagens atrativas. As duna são particularmente atrativas para passeios a pé ou de carro e para o desenvolvimento de campos de golfe, alojamentos, zonas de campismo e caravanas. Os efeitos incluem a "disrrupção de zonas, destruição de habitats e erosão" (Mathieson and Wall, 1982) destruindo-se, assim, o mais eficiente e barato sistema de proteção costeira.

As construções costeiras são em regra agentes de modificação da linha costeira. Os designs inapropriados, localização de espigões e estruturas similares podem alterar ou acelerar os processos de formação das costas, originando erosão e deposição. As marinas são um tipo particular de construção que podem originar este tipo de impactos. Outro grande causador de impactos seria o ruído. Entende-se por ruído o "estímulo sonoro cujo conteúdo informativo não apresenta interesse ou é indesejável para o auditor" (SILVA, 1975, pág. 35). Apesar do ruído 
não alterar ou estragar o ambiente física ou quimicamente, é considerado um poluente se em quantidade e intensidade suficientes para causar danos psicológicos aos indivíduos.

A atividade turística, fomentando a concentração de população humana em um determinado local, é uma fonte potencial de ruído que pode contribuir para a degradação ambiental e cuja intensidade varia com as circunstâncias. O turismo pode contribuir com várias fontes de ruído: as resultantes da construção e exploração dos equipamentos turísticos, a exploração de discotecas, parques de diversão, bares e restaurantes, fonte de freqüentes reclamações de residentes e turistas, além de música alta, que, quando propagada em meio natural, pode prejudicar ou espantar espécies da fauna de seus habitats.

O turismo é responsável pela geração de ruído em conseqüência de:

- Aumento de tráfego e uso de veículos recreativos(barcos a motor, motas de água, aeroplanos, buggies, etc). O ruído provocado por estes veículos é resultado da concentração de turistas e pode atingir desconforto e irritação para residentes e outros turistas;

- O aumento de tráfego aéreo devido ao turismo acentua o impacto ambiental afetando residentes (particularmente os que vivem próximo dos aeroportos), turistas e comunidades animais vizinhas. É também particularmente grave quando os aviões sobrevoam zonas de lazer e descanso como é o caso das praias;

- Os próprios turistas também são grandes fontes de ruído de causas múltiplas. 


\subsubsection{Os Resorts e o Uso da Paisagem}

O turismo tem um aspecto urbanizador. As atrações naturais são insuficientes para satisfazer o turista, que têm que ser complementadas com outras facilidades turísticas e infra-estruturas de suporte. O desenvolvimento turístico acelerado e sem o enquadramento de linhas de orientação e planeamento levam freqüentemente àquilo que é conhecido como poluição visual ou arquitetônica. (Mathieson and Wall, 1982)

Na visão de Mathieson and Wall (op.cit.), o mal uso da paisagem resulta na justaposição de edifícios com diferentes estilos arquitetônicos e a falha na integração das infra-estruturas com as diferentes características do ambiente natural. O recurso a materiais de construção pouco próprios, nas superfícies externas, é outro fator que contribui para a poluição visual devendo ser privilegiados os materiais locais. O uso de publicidade desenquadrada, bem como a proliferação de cabos de eletricidade e linhas telefônicas aéreas, antenas (elementos pouco atrativos), traduzem outros tantos fatores de poluição visual.

Inskeep (1991), autoridade no planeamento, defende que devem ser incorporados no design urbano todos os elementos de design local e que se deve promover a consistência com as características do ambiente natural. Deverá ainda ser privilegiada uma arquitetura paisagística apropriada para a atratividade do Resort sem denegrir o aspecto funcional. A arquitetura paisagística e aparência do ambiente total devem incluir e respeitar os seguintes elementos:

- Plantas: deverão, sempre que possível, ser utilizadas plantas endêmicas que crescem bem no ambiente natural e reforçam o caráter natural do local, podendo no entanto ser utilizadas plantas exóticas.

- Cursos de água: estes deverão ser concebidos de forma a permitir 
manutenção e conservação da água (por exemplo, reciclagem de água usada nas fontes ornamentais e quedas de águas).

- Passagens: deverão, para além das questões de segurança, ter um enquadramento estético.

- Iluminação : também a este nível deverão ser privilegiadas as questões de segurança, sem esquecer o elemento estético, nomeadamente, contribuindo para realçar os edifícios em paisagem.

De forma a garantir uma integração equilibrada, Inskeep (op. cit) defende, também, que deverão ser definidos e respeitados outros critérios, nomeadamente:

- distâncias mínimas requeridas entre edifícios (importante sentido de abertura e espaço suficiente para paisagem, privacidade e questões de segurança). O não respeito deste critério provoca a obstrução da vista cênica ou o chamado ribbon development;

- distâncias mínimas requeridas em relação à linha de costa de 30 a 50 metros podendo ser superior a 50 metros em função das circunstâncias;

- criação de parques de estacionamento nas ruas;

- fornecimento de largos espaços para estacionamento de autocarros;

- critérios de densidade, os quais não deverão exceder determinados limites sob pena de prejudicar a harmonia do projeto. Refira-se por exemplo, que a densidade máxima no Resort Quinta do Lago não ultrapassa as 80 pessoas por hectare; 
- limite da altura dos edifícios. Aspecto particularmente importante influenciando o caráter do destino turístico. Altera a visibilidade e expectativas dos turistas que pretendem uma mudança ambiental relativamente aos seus lugares de origem;

O não cumprimento destes critérios leva, em última análise, à perda do caráter único do território, fator de vital importância na formação de atrativos turísticos.

\subsubsection{Os Resorts e o Ecoturismo}

O ecoturismo visa promover a prática do turismo com a conservação do meio ambiente. Hoje está claro que o fator de sustentabilidade é o que gera o desenvolvimento da atividade ecoturística e que viabiliza a preservação da natureza e os seus diversos ecossistemas, que são os produtos consumidos pelos turistas ecológicos. Os Resorts agregam um pouco destes valores do turismo, pois são complexos turísticos criados dentro de áreas naturais, absorvendo suas paisagens e matérias primas.

Os ecoturistas são pessoas admiradoras da natureza pura. Eles podem ter diversos interesses, desde a prática de esportes até o estudo científico dos ecossistemas naturais. Como afirma Yázigi (2001) que nós não somos ecoturistas, nós estamos ecoturistas. Há uma visão calcada na idéia de que o ecoturismo ainda é visto de forma errada, e que muito ainda deve ser feito para que os escassos bens naturais não sejam completamente degradados por iniciativas mal sucedidas.

Os turistas que consomem o produto Resort, não são necessariamente amantes da natureza, mas consomem, direta ou indiretamente os bens naturais, gerando, assim, impactos no meio natural onde se encontra instalado o Resort. $\mathrm{O}$ 
funcionamento do turismo em áreas naturais envolve extrema cautela. A conscientização das populações que residem em áreas turísticas, acerca do funcionamento e benefícios do turismo, é de grande valia para o desenvolvimento da atividade, bem como a conscientização dos turistas e empreendedores turísticos frente a preservação ambiental.

A implantação de grandes complexos turísticos em áreas naturais requer ainda mais cuidados. O impacto causado nas áreas naturais são consideráveis quando um hotel de médio à grande porte, como são os Resorts, são implementados em regiões naturais de praias e mangues.

O conceito de turismo sustentável, como um fenômeno de desenvolvimento, vem sendo debatido desde a década passada. O termo sustentável vem sendo utilizado desde os últimos 20 ou 30 anos, originado dos antigos modelos de planejamento urbano. Como o turismo para ser sustentável deve atender às necessidades dos turistas atuais sem comprometer a possibilidade do usufruto dos recursos pelas gerações futuras, temos que ter consciência de que muitas mudanças devem ser feitas nos numerosos tipos de turismo para que estas prerrogativas passem a ser uma realidade na atividade.

No caso dos Resorts, a sustentabilidade deve ocorrer para que sejam potencializadas as virtudes da atividade da demanda, que é composta pelos turistas consumidores do produto Resort, e minimizados os impactos negativos. $O$ planejamento do uso e preservação sempre deve existir, pois o planejamento é um processo sem fim. Mesmo sendo o complexo Resort o maior causador dos impactos nas áreas naturais, direcionar o capital obtido pelo consumo deste produto para a manutenção da natureza e população local também é estar implementando a sustentabilidade. 
Fazendo uma adaptação de Krippendorf (1982), Lane $(1989,1990)$ e Godfrey (1996), podemos conceituar, em foco geral, o turismo sustentável versus o não sustentável:

QUADRO 01 - Turismo sustentável x não sustentável

\begin{tabular}{|c|c|}
\hline SUSTENTÁVEL & NÃO-SUSTENTÁVEL \\
\hline \multicolumn{1}{|c|}{ Conceitos Gerais } \\
\hline Desenvolvimento lento & Desenvolvimento rápido \\
\hline Desenvolvimento controlado & Desenvolvimento descontrolado \\
\hline Longo prazo & Curto prazo \\
\hline Qualitativo & Quantitativo \\
\hline Controle local & Controle remoto \\
\hline Estratégias de Desenvolvimento \\
\hline Mão-de-obra local & Mão-de-obra importada \\
\hline Arquitetura nativa & Arquitetura de outros tipos \\
\hline Comportamento do Turista \\
\hline Consciência preservacionista & Sem preparo mental \\
\hline Fala baixo & Fala alto \\
\hline Repete as visitas & Improvável que volte \\
\hline
\end{tabular}

(Adaptação de Krippendorf (1982), Lane (1989, 1990) e Godfrey (1996))

O quadro demonstra as diversas variáveis que influenciam a viabilidade do turismo sustentável. O planejamento sustentável deve ter prerrogativas como estas citadas no quadro, para melhor dimensionar as características a serem alcançadas na sustentabilidade de um destino turístico.

\section{UNIDADE 3 : POR UM NOVO CONCEITO DE “RESORT ECOLÓGICO”}

\subsection{ESTUDO DE CASO: COMPLEXO COSTA DO SAUÍPE}

Para a proposta do Resort Ecológico, foi analisado o estudo " A Responsabilidade Socioambiental da Indústria do Turismo e do Lazer: o Empreendimento Costa do Sauípe" de autoria de Lopo Neto (2003). Esta análise serviu como base para a formatação do Resort Ecológico, que é um projeto criado para corrigir os erros cometidos pelos Resorts existentes e para colocar em prática os ideais de sustentabilidade. 
Segundo o estudo realizado por uma empresa internacional, contratada pela holding Norberto Odebrecht, foi identificado no complexo Costa do Sauípe dois segmentos apropriados para o Resort: o ecoturismo e a demanda por parque hoteleiros de padrão internacional. Neste mesmo estudo foi constatado que dos cinco hotéis de maior qualificação encontrados na cidade de Salvador, nenhum atendia às expectativas dos viajantes internacionais.

O projeto Costa do Sauípe está presente no EIA/RIMA (ECOPLAM, 1997 a, b) onde consta que o projeto foi elaborado por técnicos nacionais e internacionais "com rigoroso planejamento estratégico" figurando uma destinação turística de "padrão internacional". A constatação de Lopo Neto (2003) frente ao empreendimento contradiz o que é dito pela ECOPLAN, pois ele, em sua dissertação de mestrado, viu que a situação fundiária da comunidade local foi agravada, ainda na fase de pré construção do complexo turístico, através de problemas gerados pela área escolhida para abrigar o Resort. O estudo de Stilfeman (1997), de acordo com Lopo Neto, comprova que a construtora do complexo não estava preocupada com os danos que as comunidades locais viessem à sofrer.

\subsubsection{Impactos Socioambientais Provocados pelo Empreendimento Costa do} Sauípe

O gestor da APA Litoral Norte, local onde se encontra o complexo Costa do Sauípe, fez o relatório no 1317/2000 para a destinação turística do local. Este relatório apontou os seguintes problemas, problemas estes que servem como base para a formatação do Resort Ecológico:

No espaço delimitado pelos hotéis, ballroom e Vila Nova:

- a supressão da vegetação típica de restinga;

- a impermeabilização do solo; 
- a construção de valas para água pluviais no braço do rio Santo Antônio;

- pilhas de areia, utilizadas na execução das obras civis, avançando para o substrato do manguezal do rio Santo Antônio;

- lavagens das betoneiras com descarte dos resíduos contendo cimento no solo e espelho dágua do rio santo Antônio;

- afugentamento da fauna existente;

- exposição de lixo doméstico e restos de obras próximo à margem direita do rio Santo Antônio, próximo ao estuário e laguna;

- lançamento de despejos contendo resíduos de tinta e odor característico de esgoto, no braço do rio Santo Antônio;

- instalação da encosta do cordão duna, decorrente da implantação de ponte de madeira, que possibilita o acesso para a faixa de praia;

- interrupção do fluxo normal das águas do braço do rio Santo Antônio que corre paralelo ao Cordão Dunal;

- implantação do Ballroom dentro dos limites da faixa de preservação permanente sem obedecer o recuo mínimo estabelecido pelo Código Florestal Lei $n^{\circ} 4.771$ de 15 de setembro de 1965;

- alteração cênica, em razão da construção de bancos de areia no espelho d'água da lagoa existente nos fundos das pousadas;

No Spa:

- supressão de vegetação fixadora de dunas externas;

No campo de golfe e cercanias:

- alteração da morfologia das dunas externas; 
- remoção de vegetação para abertura de vias de acesso para transporte de concreto;

- substituição da vegetação fixadora de dunas por gramíneas;

No centro eqüestre:

- erosão

- substituição de vegetação fixadora de dunas nativas por gramíneas exóticas;

Na lavanderia central:

- lançamento de efluentes em córrego da bacia do rio Sauípe;

- possível emissão de efluentes contendo sabão e desinfetante, os quais podem causar problemas par o sistema de tratamento da ETE - lagoas facultativas e de maturação, devendo ser apresentada solução técnica;

- possíveis emissões de gazes (poluentes atmosféricos), decorrentes do funcionamento das caldeiras utilizadas no processo de lavagem industrial;

No posto de combustível:

- mudança cênica, em virtude do aplanamento da região de dunas;

No alojamento de funcionários e cercanias:

- mudança da paisagem em função de cortes nas encostas;

- lançamento a céu aberto de esgotos, in natura, procedentes das edificações, em córrego da bacia do rio Sauípe;

Na área do sistema viário:

- impermeabilização do solo; 
- erosão na via de acesso para as instalações da academia de golfe, como também na via de acesso redutor de velocidade nas cercanias da rodovia;

- aterro da margem do Brejo dos Paus;

- canalização do rio da Vaca Tonta, pertencente à bacia do rio Sauípe;

No que se refere a infra-estrutura: linha de transmissão/distribuição:

- retirada da vegetação nativa, ao longo do traçado previsto e de sua faixa de servidão, para a implantação da linha de transmissão/distribuição de energia alétrica na área do empreendimento;

No córrego Vaca Tonta:

- barramento de 6 metros de altura com berma de equilíbrio com base de 60 metros de largura e dragagem do fundo;

- supressão da vegetação típica de área alagadiça e restinga de porte arbóreo;

- corte e queima da vegetação arbórea nativa de área alagadiça e ciliar;

- afugentamento da fauna;

Nos recursos hídricos:

- as águas coletadas nos brejos, inseridos na área do empreendimento, apresentam pH levemente ácido, tendo em vista a presença de agentes poluentes orgânicos;

- presença de coliformes fecais nas águas do rio Sauípe à jusante da área urbana da Vila de sauípe;

- presença de agroquímicos nas águas das lagoas artificiais usadas para irrigação, bem como nos demais corpos hídricos, situados na área de influência do campo de golfe; 
- presença de óleo diesel no espelho d'água do rio Santo Antônio, Brejo dos Paus, Brejo Felizardo e no solo, em decorrência de vazamentos;

- vazamento de óleo dos tonéis armazenados diretamente sobre o solo e vasilhames de lubrificantes utilizados nos veículos;

$\mathrm{Na}$ área de praia:

- presença de lixo, na faixa de praia, em frente ao empreendimento;

Na central de pré - moldados:

- carregamento dos resíduos de cimento presentes na águas de lavagem dos caminhões betoneiras;

- emissão de particulados para a atmosfera;

- armazenamento de matérias-primas usadas na fabricação do concreto diretamente sobre o solo e a céu aberto;

Impactos nas localidades de Vila Sauípe e Porto de Sauípe:

- de acordo com o Centro de Recursos Ambientais do Estado da Bahia (CRA) a Vila Sauípe e o Porto de Sauípe foram as localidades que mais sofreram impactos com a instalação do Resort.

Vila Sauípe (só figuram impactos negativos):

- construção de posto policial pela construtora, seguida da depredação em virtude de ele não ter sido operacionalizado;

- inadimplência da construtora na construção da casa de farinha comunitária e da recuperação da praça pública para com a comunidade local, compromissos estes assumidos em audiência pública pela construtora Odebrecht com a comunidade local;

- rejeição unânime ao novo cemitério por causa da perda de seus 
referenciais;

- implantação da rede para esgotamento sanitário pelo poder público estadual, todavia com seus efluentes despejados no rio Sauípe;

- coleta de lixo realizada de forma irregular;

- abastecimento de água promovido pelo poder público estadual com custo elevado para o padrão econômico da população;

- ausência de política de capacitação de mão-de-obra destinada à indústria do turismo e do lazer;

Porto de Sauípe:

Impactos Negativos:

- aumento populacional desordenado;

- aumento real de contingente populacional sem ocupação definida;

- implantação de clima de violência urbana;

- evasão de pescadores para o segmento de serviços;

- inflação no preço de pescado e mariscos em razão da maior procura por estes produtos;

- aumento da prostituição;

- posto de saúde construído pela Odebrecht com baixa resolutividade;

- posto policial construído pela Odebrecht funcionando apenas em fins de semana;

- a não conclusão do sistema de abastecimento de água e do saneamento básico para toda a população pela EMBASA (Governo do Estado); 
- ausência de uma política de educação ambiental, tal qual se comprometeu o Empreendimento no EIA/RIMA (ECOPLAM,1997 a, b);

Impactos Positivos

- estímulo à atividade comercial;

- aumento do mercado consumidor para os pescados e mariscos capturados na região;

- cursos de capacitação profissional voltados para a indústria do turismo;

- coleta regular do lixo doméstico;

- coleta de esgoto doméstico;

- melhora no serviço de distribuição de água;

Conclui-se assim que o Resort Costa do Sauípe exemplifica bem a problemática acerca dos grandes complexos hoteleiros que causam, devido ao seu tamanho, grandes impactos no meio ambiente. Todos os problemas descritos são, direta ou indiretamente, relacionados a falta de um Planejamento Sustentável. O Resort Ecológico baseia-se no uso do Planejamento Sustentável para o sucesso do empreendimento.

\subsection{MONTAGEM DO PROJETO RESORT ECOLÓGICO}

Este trabalho propõe um projeto de Resort de temática ecológica a ser empregado em qualquer área natural, segundo o interesse de quem deseja tornálo uma realidade. A palavra Resort, neste projeto, é considerada como um "hotel temático". O "Resort Ecológico" é um hotel de temática ecológica, administrada por profissionais de turismo, bacharéis, que objetivam o estudo dos impactos causados pelo turismo em áreas naturais e que tratarão do Resort Ecológico como uma ferramenta para a propagação da Cidadania Ambiental, alcançada por meio 
da Educação Ambiental

A importância de serem bacharéis em turismo no controle do hotel é o fato de estes serem capacitados no trato direto com o turismo. O Resort Ecológico terá este caráter de hotel escola pois além de administrarem o hotel, os gestores estarão coletando dados para compor as estatísticas brasileiras do ecoturismo, que são escassas, bem como avaliando todas as características e problemas do chamado trade turístico, na natureza.

\subsubsection{A Problemática dos Resorts e Sua Influência no Resort Ecológico}

O primeiro grande problema acerca dos Resorts, com base no que é apresentado no estudo de caso da Costa do Sauípe, é o tamanho exagerado de sua estrutura. O projeto Resort Ecológico está distante desta realidade. O Resort Ecológico de imediato procura a integração com o meio natural de forma que a disposição horizontal de sua estrutura não ocupe áreas destinadas à ocupação humana existente, nem mesmo áreas de preservação da natureza.

Analisando a problemática acerca do Complexo Costa do Sauípe, pode-se estipular os limites para o Resort Ecológico de forma que este não cometa os mesmos erros analisados. O fator principal para que estes excessos não ocorram é o uso do Planejamento Sustentável.

\subsubsection{Uso do Planejamento Sustentável}

Os países latino-americanos sofrem com a dependência imposta pelos chamados desenvolvidos. A dependência é um fator histórico a ser considerado, pois as tomadas de decisões estão sempre atreladas a fatores que extrapolam as políticas nacionais. O tão almejado desenvolvimento esbarra nas colunas das imposições mercantilistas dos países dominantes (MOLINA E., 2001). 
A América Latina tem um sério problema quanto a distribuição de renda. O bom planejamento deve respeitar o político, o social e o ecológico. Este planejamento deve ter a sustentabilidade como meta. O uso controlado dos recursos é uma tomada de decisão de extrema importância para o desenvolvimento de um país, como no caso da relação turismo/região, resort/região. No segmento Ecoturismo, a sustentabilidade está intrínseca à atividade. O uso da natureza pelo Ecoturismo é visto como uma parceria, onde a natureza fornece seus recursos e espaço e o Ecoturismo contribui com benefícios sociais e econômicos para a localidade. O planejamento é a ferramenta utilizada para assegurar o uso sustentável destes recursos.

De acordo com Faria (2001, pág. 16) "o conceito de sustentabilidade pode ver-se transformado em uma questão mais política que ambiental, reflexo de conflitos e da pluralidade de atores envolvidos", demonstrando que o interesse de alguns empreendedores em apenas atender a uma necessidade de investimento, sem se preocupar com características de um local e os problemas que possam vir a ocorrer, podem fazer da sustentabilidade um fator apenas citado no papel, e não colocado em prática.

A proposta de uso dos recursos de forma sustentável, deve visualizar a natureza "emprestando" estes recursos para o sistema. O empréstimo requer um retorno de mesma proporção, logo, a preservação dos recursos é perpetuada. $O$ monitoramento permanente de profissionais de turismo no Resort Ecológico é uma das ferramentas do projeto Resort Ecológico para a obtenção de um sistema de sustentabilidade ecológica.

O turismo pode gerar divisas que auxiliem o desenvolvimento de um país, mas só com o planejamento devido isto será possível. Caso contrário, o mau emprego do turismo pode agravar vários dos problemas existentes neste país. $\mathrm{O}$ turismo tem históricos de agravamento no campo social como por exemplo Cancún, onde a instalação de vários Resorts aumentou a disparidade social e 
econômica entre turistas e residentes. Estes mesmo problemas são levantados no caso do Resort Costa do Sauípe. O planejamento pode piorar a situação de uma região. O mau uso do planejamento decorre na falha de levantamento das características e, consequentemente, na falha de tomadas de decisões. Decisões erradas em um processo de planejamento, são estímulos para acirrar ainda mais os problemas existentes.

Segundo Molina (2001 pág. 79), "O planejamento é o resultado de um processo lógico de pensamento, mediante o qual o ser humano analisa a realidade abrangente e estabelece os meios que lhe permitirão transformá-la de acordo com seus interesses e aspiracões". O planejamento deve considerar vários fatores, como políticos e sociais, para que seus objetivos sejam alcançados. A realidade a ser inserida o planejamento deve ser bem analisada através de um diagnóstico que servirá de base para a formatação das decisões a serem tomadas. Na concepção correta de um Resort Ecológico, o levantamento de metas é fundamental para o sucesso do empreendimento.

Toda esta análise da questão do planejamento na América Latina, tendo a problemática do Resort Costa do Saípe como exemplo, nos mostra que o planejamento é primordial para qualquer atividade, que a realidade precária da América Latina atrapalha o turismo e que o turismo da forma que é feito não é capaz de gerar desenvolvimento algum. Já sabemos que o crescimento, por si só, é insustentável do ponto de vista ambiental. O Resort Ecológico utiliza o Planejamento Sustentável como ferramenta para o desenvolvimento de uma consciência ambientalmente correta e de uso correto dos recursos. 


\subsubsection{Sistema Resort Ecológico}

Temos abaixo descrito o Sistema Resort Ecológico.

QUADRO 02 - Sistema Resort Ecológico

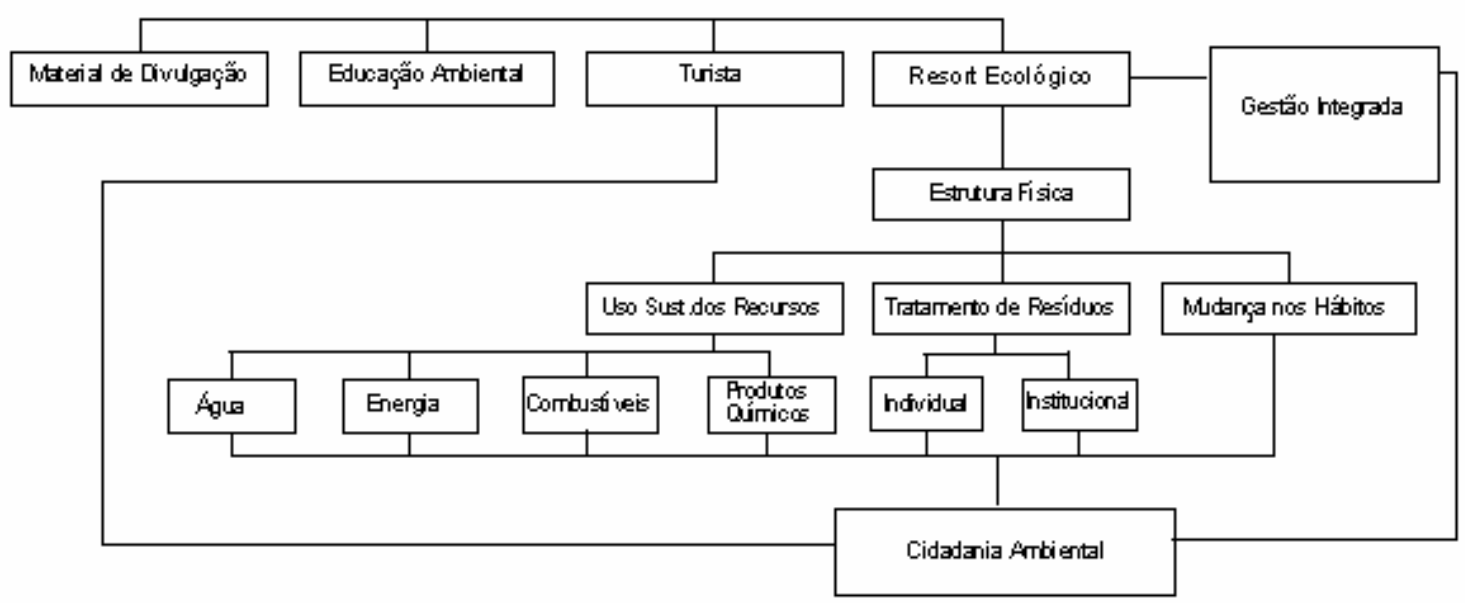

O Sistema Resort Ecológico mostra as relações entre as partes componentes do complexo e as ações a serem tomadas para o funcionamento da sustentabilidade. Em uma primeira etapa, temos o primeiro contato do turista com o Resort Ecológico através de seu material de divulgação. A importância deste material é muito grande pois nele está contido todas as prerrogativas do uso sustentável dos recursos, através de diretrizes que expressam a formação da educação ambiental para o turista, desde a contratação dos serviços até a sua conclusão.

Dentro do Resort Ecológico vemos os componentes descritos como Estrutura Física, que incluem a Sede, Quartos, Spa, Camping, Centro Cultural e demais estruturas. O Sistema demonstra a importância de que estas partes estejam integradas com as ações de cunho sustentável, ações estas que darão ao turista, como produto final, uma Cidadania Ambiental. 
O Uso Sustentável dos Recursos é a meta dentro do Resort Ecológico. A forma como são usados corretamente os recursos é mostrado ao turista no Resort, que não só aprende como usar, mas que, de fato, estará utilizando estes recursos de maneira consciente e sustentável. Ao utilizar os recursos, haverá a geração de resíduos que serão tratados ecologicamente, e dentro do possível, reutilizados de alguma maneira. Assim, a sustentabilidade será praticada em três etapas: antes, com o próprio uso, durante, no processamento dos resíduos, e depois, no produto obtido com o tratamento destes resíduos, além da conscientização do turista deste fluxo sustentável.

Analisando o Uso Sustentável dos recursos, vemos que este ramifica-se em água, energia, combustíveis e produtos químicos. Estes recursos são escassos e, de alguma forma, o turista terá acesso ao uso e a manutenção destes. A forma apresentada no Resort Ecológico será através de mecanismos que permitem o uso suficiente e necessário dos recursos. Por exemplo, o uso do recurso água, por meio de torneiras com temporizadores, é poupado consideravelmente o gasto, mas que também é explicado ao turista formas de energia alternativas, como eólica e solar, que devem ser apresentadas como parte importante de geração ecológica de energia. O turista poderá compreender a importância de adoção de tais medidas, o que contribui para sua visita. Os produtos químicos como xampu, terão destinação especial devido à captação específica e tratamento necessário, para evitar impactos negativos no meio ambiente. Os combustíveis utilizados em máquinas e veículos, deverão ter a sua emissão de gases reduzidas por meio de filtragem. Esses princípios serão disseminados e poderão ser assimilados corretamente pelo turista.

O tratamento dos resíduos terá rigor individual e institucionalmente, na seleção e classificação. A destinação será a reutilização do lixo tratado ou sua eliminação sem resíduos. Informar o turista de todo o processo é fornecer a ele uma forma de pensar corretamente, introduzindo a importância do mínimo impacto no meio ambiente, propiciando uma mudança de valores que inclui o bom uso dos 
recursos. Com isso, o hábito de uso sustentável dos recursos que poderá extrapolar sua permanência no Resort e atingir a sua rotina cotidiana.

Todas as partes do sistema levam a uma segunda etapa que é a formação da Cidadania Ambiental. A planificação do Resort Ecológico, através de um sistema, mostra os caminhos que o fator sustentabilidade deve percorrer e atuar para que o ser humano, no nosso caso tratado como turista, seja um cidadão mais completo quando voltar a sua casa, e que passe para seus semelhantes o ideal de usar e conservar. A Cidadania Ambiental é isso, o dever de conscientizar e a responsabilidade de preservar.

\subsubsection{O Resort Ecológico e Sua Interação com as Comunidades}

A comunidade terá ação direta na implementação e controle do Resort. A capacitação para a montagem da estrutura bem como as aulas de educação ambiental e administração hoteleira serão necessárias para a efetiva participação da comunidade local no empreendimento. A Cidadania Ambiental é um fator que se estende à comunidade, que terá papel de divulgar e praticar as prerrogativas de uso sustentável dos recursos.

A função de guia de turismo será gerida por um turismólogo com capacitação na área. Este terá apoio de moradores locais, pois estes possuem o conhecimento do terreno que compreenderá a área utilizada para instalação do complexo turístico.

No empreendimento, a valorização da cultura local será uma das principais metas. Festas locais tradicionais serão atrações para os turistas, que terão um conhecimento prévio da cultura da comunidade através do Centro Cultural instalado na sede do Resort, composto por materiais que caracterizem a história do local, os modos de se vestir, as atividades econômicas e tudo que esclareça ao 
turista a importância de se preservar as comunidades tradicionais no Brasil.

\subsubsection{Propostas para Caracterização Física e Sustentável do Resort Ecológico}

Para que os erros cometidos no empreendimento Costa do Sauípe não ocorram no projeto Resort Ecológico, algumas propostas de caracterização da estrutura deste empreendimento devem ser apresentadas. A seguir temos uma tabela, retirada do Manual da WWF de Ecoturismo de Base Comunitária (2003, pág. 218) empreendimento ecológico contra um não ecológico:

Quadro 03: Diferenças entre Ecopousada e Pousada/Hotel:

\begin{tabular}{|l|l|}
\hline \multicolumn{1}{|c|}{ Ecopousada } & \multicolumn{1}{c|}{ Pousada/Hotel } \\
\hline $\begin{array}{l}\text { Pequena área construída em relação à área } \\
\text { verda }\end{array}$ & Pode ter praticamente toda a área construída \\
\hline Incentiva a culinária local & Não incentiva, necessariamente, a culinária local \\
\hline Valoriza mão de obra-local & $\begin{array}{l}\text { Mão-de-obra especializada ou de grandes } \\
\text { centros }\end{array}$ \\
\hline Proporciona lazer e educação & Proporciona Lazer \\
\hline Construção mais rústica & Construção mais luxuosa \\
\hline $\begin{array}{l}\text { Estabelecida em local com atrativos } \\
\text { naturais/culturais }\end{array}$ & Maior flexibilidade para a localização \\
\hline
\end{tabular}

\section{(A) Estrutura Física}

\subsubsection{Centro Cultural}

O Centro Cultural deve abrigar a história da comunidade local, contada através de sua arte e seus costumes. O acervo do centro deve possuir peças que delimitem uma característica que é única ao povo local, uma identidade que faça com que os visitantes sintam-se interessados em aprender e respeitar a pluralidade de culturas existentes no Brasil.

A conscientização ambiental é aqui tratada de forma que o ser humano veja a manutenção de bons costumes como uma viabilização do bem estar das 
próximas populações. A sustentabilidade, em caráter antropológico, é primeiro analisado e aceito para que os recursos sejam também preservados. O ser humano só vai se preocupar com as gerações vindouras quando se importar com a sua geração e com aquelas que o precederam.

\subsubsection{Sede}

Localizada em um ponto estratégico, a Sede é a recepção do hotel. Além de conter todos os equipamentos e materiais de uso no hotel, é na Sede que estão seus administradores. Esta edificação, assim como todas as outras no Resort Ecológico, devem propor a idéia de ocupar pouco espaço e ter causado mínimo impacto no ambiente onde será construída. Esta proposição é viável através de utilização de materiais conhecidos como ecológicos, através de construções de tamanhos reduzidos, quando comparados com edificações de um Resort como Costa do Sauipe. O aspecto deve ser rústico, para não entrar em contraste com o meio ambiente natural.

O zoneamento ecológico da área utilizada nas edificações deve ser feito para a mitigação dos impactos causados na instalação. Tamanho e declividade são fatores de vital importância para questões como drenagem de água. Os acessos devem ser facilitados entre as estruturas existentes no Resort Ecológico evitando distâncias muito grandes que venham a perpetuar impactos maiores devido ao fluxo de pessoas.

\subsubsection{Quartos}

Os quartos devem ser simples. O hotel deve possuir uma das características que definem um Resort: a temática. A temática principal é o "ser humano em contato com a natureza", o que leva a projetar uma decoração prevalecente com estilo sóbrio. A captação dos resíduos deve ser cuidadosa e 
controlada. São nos quartos que devem estar instalados os principais mecanismos que viabilizam o uso sustentável dos recursos.

Materiais de normas de conduta na natureza, são disponibilizados ao público nos quartos onde estiverem alojados. Toda forma de propagar a questão da importância de usar e conservar a natureza é válido e deve ser utilizado no Resort Ecológico.

\subsubsection{Cozinha}

A cozinha deverá ser terceirizada e dentre os cozinheiros estão incluídos moradores locais capazes de preparar comidas típicas, havendo um controle de nutricionistas. Parte da comida, frutas e verduras, oferecidas pela cozinha, será proveniente do cultivo dos alimentos na horta e no pomar do Resort ou por famílias da própria comunidade. A reutilização de cascas de alimentos e outros resíduos que iriam para o lixo, serão reaproveitados de forma a propagar a idéia de que o lixo tem sua parcela de contribuição na sustentabilidade.

\subsubsection{Spa}

O Spa será gerenciado por profissionais formados nas áreas afins, como Nutrição e Medicina. A área delimitada para o Spa é uma área em particular no hotel, pois representa um processo de reintegração social e psicológica para o obeso. A sua inserção nas demais atividades é gradativa e de acordo com a vontade da pessoa de praticar tudo aquilo que os demais hóspedes, que podem ter outros interesses, venham a praticar. 
O pressuposto analisado para este caso é o de que a pessoa que procura o Spa está interessado em perder peso e modelar o corpo. No Resort Ecológico, esta pessoa é vista como um turista que será incentivado a se sentir feliz com tudo aquilo que venha a fazer nas dependências do hotel.

\subsubsection{Camping}

A área do camping deve ser em um local que já tenha características para abrigar os campistas, sem que seja necessário alterar o ambiente natural. 0 comportamento dos campistas deve ser ecológico, seguindo prerrogativas de não causar impactos como fogueiras e retirada de materiais da natureza.

Junto à área de camping, estarão agregados locais para prática de esportes ligados à natureza como natação, arvorismo e escaladas, todos com acompanhamento de profissionais capacitados na área.

\section{(B) Construção Permanente da Sustentabilidade do Fluxo Turístico}

\subsubsection{Coleta de Lixo}

A coleta de lixo, principal problema em estruturas de grande porte, deve ser muito bem analisada. O uso de centrais ecológicas de tratamento e reciclagem do lixo é um recurso bem visto no Resort Ecológico. A contribuição de coleta de lixo individual de cada parte do Resort faz com que o controle seja mais rigoroso.

\subsubsection{Programa de Educação Ambiental}

A conscientização ambiental é meta principal quando se trata de Ecoturismo. O Resort Ecológico possui um estreito relacionamento com 0 Ecoturismo e uma conseqüente necessidade de ensinar ao ser humano como se 
portar frente a natureza. A interpretação ambiental é um instrumento da educação ambiental para que o ser humano entenda o ambiente natural que o cerca e que visa informar o turista acerca do limite de suas ações no ambiente natural.

A Educação Ambiental está diretamente relacionada com a mudança de valores e atitudes, fazendo o ser humano refletir sobre a visão que tem de si mesmo e a relação com o meio ambiente. Conforme definição da Unesco (1987) a Educação Ambiental é um processo permanente no qual a comunidade e o indivíduo tomam consciência do meio ambiente em que vivem e adquirem conhecimento para buscar soluções para os problemas ambientais presentes e futuros.

A interpretação ambiental toma como base alguns princípios como personalidade e experiência das pessoas a que são dirigidas a educação, uso da informação e significados dos objetos estudados e auxílio multidisciplinar, como por exemplo, história e ciência natural. A interpretação por parte dos atores envolvidos no turismo faz com que a educação torne-se algo real e ativo em suas mentes, tornando os receptores atuais, emissores da educação ambiental num futuro próximo. ${ }^{4}$

Atividades ligadas à educação ambiental devem ser oferecidas mesmo antes da estada do turista no Resort Ecológico com o objetivo de estender a conservação à nível nacional e não somente nas dependências do complexo. $O$ programa de educação ambiental é utilizada para que todos atores envolvidos no Resort Ecológico tornen - se cidadões ambientais.

\footnotetext{
${ }^{4}$ Manual de Ecoturismo de Base Comunitária da WWF Brasil, 2003 pág. 262
} 


\section{UNIDADE 4: RECURSOS HUMANOS PARA O RESORT ECOLÓGICO}

\subsection{O BACHAREL EM TURISMO E O RESORT ECOLÓGICO}

A função do bacharel em turismo no Resort Ecológico é primordial. O controle de todas ações, tanto antes como após a concepção do empreendimento, devem ser acompanhadas por profissionais da área com o intuito de regular estas ações de forma sustentável.

Com participação direta no controle das atividades dentro do Resort Ecológico, os dados levantados pelo Turismólogo quanto ao turismo de caráter ecológico praticado no Resort, servirão como informação a ser catalogada para constituição da escassa literatura do Ecoturismo no Brasil.

\subsection{METODOLOGIA DE ABORDAGEM SUSTENTÁVEL}

Os métodos a serem utilizados para a gestão integrada e para o fomento de pesquisas, envolvem estudos dos impactos no meio ambiente onde forem instalados os complexos dos Resorts Ecológicos. O uso de diversas metodologias visam dar ao turismólogo responsável pelo controle do complexo, uma ferramenta para controle direto dos recursos e das ações na natureza. Modelos vão dimensionar, em qualidade e quantidade, os resultados das ações impostas pelos complexos nas áreas da natureza diretamente influenciadas por este, mas a metodologia final será definida em função de cada projeto.

Um exemplo de modelo de pesquisa que visa descrever os impactos com a atribuição de pontuações, pode ser mensurando, em valores de 1 a 5, o tipo de impacto imposto no ambiente. O impacto sempre ocorrerá, logo, o estudo visaria analisar se este impacto poderia ser corrigido permanentemente, devido a não causar danos irreversíveis. Sempre ter-se-ia controle sobre o estágio em que a 
danificação estaria. Com atribuição de danos entre 1 e 2, o impacto seria reversível à curto prazo em 1, e à médio prazo em 2. Com atribuição de danos em 3, o impacto pode ou não ser reversível à longo prazo. Com grau de impacto em 4, o dano seria irreversível, e estaria em um estágio avançado de degradação, restando em torno de 20 e $30 \%$ do recurso natural, e em 5 , os danos também seriam irreversíveis, sendo que o recurso já estaria escasso. Deste modo, a gestão do sistema poderia mantê-lo funcionando sempre dentro dos padrões de sustentabilidade.

Outros métodos a serem utilizados envolvem estudos aprofundados da natureza com auxílio de profissionais de várias áreas, como biólogos, geólogos e outros para que os dados obtidos nas pesquisas iniciais sejam analisados com precisão. O profissional de turismo pode, diretamente, atuar na descrição das características do turista que vem a consumir o produto Resort Ecológico e integração das diversas áreas no sistema.

Outras pesquisas podem ser exploradas pelos profissionais de turismo com o intuito de vislumbrar a idéia da interação dos turistas diretamente com a região de destino, que no nosso caso é o complexo do Resort Ecológico. Assim, os danos causados na natureza pelo complexo poderia ser delineados desde a implementação da infra-estrutura, até a interação turista/Resort.

Para o sucesso pleno no desenvolvimento de todas as partes do sistema Resort Ecológico, como descrito neste capítulo, é necessário, portanto, que haja gestão integrada. Isto significa a interação plena das partes componentes do sistema e suas relações, bem como com o controle dos profissionais envolvidos e o uso, por eles, de metodologias específicas. 


\section{UNIDADE 5: CONCLUSÃO}

Utilizar e propagar a idéia de empreendimentos "amigos da natureza", de baixo impacto e de baixa ocupação, é a saída para as crises envolvendo os Resorts. Ao diminuir o tamanho exagerado de seus complexos atuais, consequentemente, diminuirão seus impactos negativos causados à natureza. $O$ Resort Ecológico é uma destas soluções.

Essa nova postura de comportamento perante os impactos, como apresentado no trabalho, é o que vai fazer dos Resorts, e do turismo em geral, atividades lucrativas e ambientalmente corretas. Esta nova postura deixa de lado apenas a visão centrada no lucro que um empreendimento vem à gerar, e dá ao ser humano uma visão sistêmica e holística da situação acerca da atividade turística, agregando a sustentabilidade à todo o processo turístico, desde o projeto inicial da atividade, até sua implementação. Os novos paradigmas a serem explorados são valores como cooperação, conservação, qualidade, parceria e integração.

A identificação dos impactos causados por complexos turísticos no ambiente natural só tem sentido se forem considerados e integrados no planejamento do desenvolvimento destes destinos turísticos. O ideal ético de uso e preservação deve sempre estar de acordo com a época e local utilizados.

O Resort Ecológico segue algumas premissas para viabilizar a sustentabilidade, como a definição de zoneamento ecológico e sustentabilidade, especialmente da área de uso intensivo, respeitando as áreas de preservação permanentes, protegendo a qualidade dos recursos hídricos, envolvendo a comunidade local em todas atividades, fazendo um levantamento de inventário de fauna e flora e utilizando efetivamente formas de geração de energia alternativas e ecológicas. O envolvimento dos atores do turismo com a preservação, vai de fato viabilizar o desenvolvimento sustentável. Ao envolver o turista e a comunidade 
com o uso sustentável dos recursos, os gestores do Resort Ecológico estarão contribuindo diretamente na formação da Cidadania Ambiental.

O levantamento de dados sobre o Resort Costa do Sauípe demonstra os problemas acerca dos complexos turísticos de grande estrutura que falharam no planejamento. A conscientização ambiental não deve ser apenas dos turistas e atores locais de um destino, mas também dos empreendedores que agem de forma imprudente e deixam de lado a tão importante sustentabilidade ambiental.

O turismo a ser praticado no Resort Ecológico é uma atividade que pensa na manutenção dos recursos como a justa lucratividade para todos envolvidos. $A$ montagem de um sistema que, de forma coesa, explica o ideal de propagação de uma Cidadania Ambiental, traz todo um universo de preocupação perante todas as etapas do turismo, desde o primeiro contato do turista com as informações acerca do destino, até sua contribuição para propagar este ideal de sustentabilidade.

O compromisso com a ética e com a sustentabilidade darão não só ao turismo, mas a todas atividades praticadas pelo ser humano, uma melhor e mais prazerosa forma de interação e cooperação, permitindo às populações que daqui a cem ou mil anos estarão pisando na Terra, um exemplo correto de manutenção da vida. 


\section{UNIDADE 6: REFERÊNCIAS BIBLIOGRÁFICAS}

BENI, Mário Carlos. Análise estrutural do turismo / Mário Carlos Beni. $-2^{\mathrm{a}}$ ed. São Paulo: Senac São Paulo, 1998.

BOO, Elizabeth. Tourism: The Potentials and the Pitfalls. Londres: The Tourism Concern/WWF,1992.

CAPRA, Fritjof. A teia da vida, uma nova compreensão científica dos sistemas vivos, São Paulo: Cultrix Ltda. 1996.

COOPER N.D ,Tourism, Principles and Practice, London: Pitman Publishing,1993.

EVER, Shirley (ed.). Beyond the Green Horizon: Discussion Paper on Principles for Sustainable Tourism. Washington: WWF, 1982.

FARIA, Dóris Santos de. Sustentabilidade ecológica no turismo/ Dóris Santos de Faria e Kátia Saraiva Carneiro. - Brasília : Editora Universidade de Brasília, 2001.

HILCHERY, T. Verão com cheiro a queimado, Ciência e Vida - Diário de Noticías, 26 de Junho, 8-9, 1994.

INSKEEP, Edward. Tourism planning. Londres: Van Nostrand Reinhold, 1991.

National and regional tourism planning: methodologies and case studies.- London/New York: Routledge.-(World Tourism Organization/Routledge Series)., 1994 
IRVING, Marta de Azevedo. Turismo: o desafio da sustentabilidade / Marta de Azevedo Irving, Julia Azevedo.- São Paulo: Futura, 2002

KRIPPENDORF, Jost. The holiday makers. Londres: Butterworth-Heinemann, 1992.

LAGE, Beatriz Helena Gelas. MILONE, Paulo César. (organizadores). Turismo: Teoria e prática. São Paulo, SP: Atlas, 2000.

LENCASTRE e FRANCO, Lições de Hidrologia, 2ed., Universidade Nova de Lisboa, Faculdade de Ciências e Tecnologia, 1992.

LAVERY, P. Travel and Tourism, 2nd Ed. Elm Publications, 1989.

LEMOS, Amalia Ines G. Turismo: impactos sócioambientais. São Paulo: Hucitec, 1996.

LOPO NETO, ANTONIO AMARÍLIO DOS SANTOS. $\boldsymbol{A}$ responsabilidade sócio ambiental da indústria do turismo e do lazer: Empreendimento Costa do Sauípe, Salvador-BA, 105p. UnB-CDS, Mestre, Gestão e Polítca Ambiental, 2003.

McINTOSH, E.R. Tourism principles, practices, philosophies. Ohio: Columbus, 1997.

MATHIESON, Alister and WALL, Geoffrey. Tourism: Economic, Physical and Social Impacts.- Harlow: Longman 1982.

MIDDLETON, J. T, Air Pollution, Collier's Encyclopedia, vol 1, New York: MacMillan Educational Company, 1990. 
MIDDLETON, V.T.C. and HAWKINS, R. SustainableTourism: A Marketing Perspective. Butterworth-Heinemann, Oxford 1998.

MOLINA E., SERGIO Planejamento Integral do turismo: um enfoque para a América Latina / Sergio Molina E., Sergio Rodríguez A. ; tradução : Carlos Valero. Bauru, SP: EDUSC, 2001.

ORGANIZACIÓN MUNDIAL DEL TURISMO. Guía práctica para el desarrollo y uso de indicadores de turismo sostenible.- Madrid: OMT, 1997.

PEARCE, Douglas G., 1949- Geografia do Turismo: fluxos no mercado e viagens /Douglas Pearce ; tradução [Saulo Krieger].- São Paulo: Aleph, 2003.

Tourist Devlopment.- Harlow: Longman, 1989.

RIBEIRO, Gustavo L. e BARROS, Flávia L. "A corrida por paisagens autênticas: turismo, meio ambiente e subjetividade no mundo conteporâneo", em SERRANO, Célia e BRUHNS, Heloísa (orgs.). Viajens à natureza: turismo, cultura e ambiente. 2ed. Campinas:Papirus, 1999.

RUSCHMANN, Doris M. Turismo ecológico no Brasil: dificuldades para sua caracterização, em Turismo em análise, vol.6, n¹, São Paulo, 1995.

Turismo e planejamento sustentável: a proteção do meio ambiente. Campinas: Papirus, 1997.

SANTOS, Milton. Técnica, Espaço, Tempo: globalização e meio técnico científico informacional. São Paulo: HUCITEC, 1994. 
SILVA, M. P. Ruído de tráfego Rodoviário, MOP Lisboa: Laboratório Nacional de Engenharia Civil, 1975.

SERRANO, Célia, BRUNHS, Heloísa e LUCHIARI, Maria Tereza (orgs.). Olhares conteporâneos sobre o turismo. Campinas:Papirus, 2000

e BRUNHS, Heloísa (orgs.). Viajens à natureza: turismo, cultura e ambiente. 2ed. Campinas:Papirus, 1999.

SWARBROOKE, John. Turismo sustentável: conceitos e impacto ambiental, vol.1 / John Swarbrooke (tradução Margarete Dias Pulido) - São Paulo: Aleph, 2000.

WAHAB, S.E.; CRAPON, S. e ROTHFIELD, P.N. Tourism marketing. Londres: Tourism International Press, 1976.

YÁZIGI, Eduardo. A Alma do Lugar: Turismo, Planejamento e Cotidiano.- São Paulo: Contexto.- (Coleção Turismo Contexto), 2001.

Turismo: uma esperança condicional - São Paulo: Global.(Global Universitária), 1999.

Sites:

Embratur: www.embratur.gov .br

Ibama: www.ibama.gov .br

Correio Brasiliense: www.correioweb.com .br 
Revistas e Manuais:

Boletim Técnico do SENAC/Serviço Nacional de Aprendizagem Comercial. Administração Nacional - Vol.1, n.1 (1974) - Rio de Janeiro: Centro de Documentação técnica do Senac., Senac, DN, 1974 - volume 30 n. 1 janeiro/abril 2004.

Turismo e Negócios. "Resorts e Parques Temáticos”, págs: 2 à 9.Editora Capixaba - E. S. Publicação do $2^{\circ}$ semestre de 2001.

Manual de Ecoturismo de Base Comunitária: ferramentas para um planejamento responsável./ [Organização: Sylvia Mitraud] - [Brasília]: WWF Brasil, 470p.:il c 2003. 